\title{
POSTURAL CONTROL IN CHILDREN BORN AT TERM ACCORDING TO THE ALBERTA INFANT MOTOR SCALE: COMPARISON BETWEEN SEXES
}

\author{
Raquel Saccani ${ }^{1}$, Nadia C. Valentini ${ }^{2}$
}

DOI: http://dx.doi.org/10.7322/jhgd.106014

\begin{abstract}
Introduction: acquisitions and changes in the motor and cognitive development of boys and girls are related not only to existing biological differences between both sexes, but also to socio-economic, cultural and family factors. Objective: to investigate the differences between sexes in the acquisition of anti-gravitational postures. Methods: the participants in this study were 638 children born at term (324 males and 314 females), from 0 to 18 months, coming from Infant Education Schools in the south of Brazil. The Alberta Infant Motor Scale (AIMS) was used to evaluate motor performance. Results: most of the evaluated children showed normal motor performance for their age $(69.7 \%)$, with nonlinear development and plateaus in postural acquisition from 15 months. There were not significant differences $(p>0.05)$ in motor performance between boys and girls from 0 to 18 months. Conclusion: motor development was similar between the sexes in the first months of life. However, throughout childhood, sociocultural differences and parents' practices seem to influence differently the process of motor acquisition and development of skills, since children are exposed to experiences in conformity with sex expectations.
\end{abstract}

Keywords: child development, risk factors, sexes, delay, assessment.

\section{INTRODUCTION}

There are numerous difficulties in understanding the motor development of children and the complexity of factors that contribute to behavioural acquisition and differences in the abilities of boys and girls over the years. The proper interpretation of the results of motor evaluations becomes difficult due to the influence of multiple factors on performance and differences between sexes due to the influence of socio-cultural interference. . $^{-4}$

According to developmental theorists, the personal desires and social expectations placed on the child from the earliest months of life can direct their behaviour and determine different acquisitions ${ }^{5,6}$. Therefore, the formation of the individual is constantly influenced by attitudes and skills that are considered appropriate for boys and girls according to socio-cultural factors, and children therefore spend time learning characteristics considered appropriate to each sex in the face of male and female behavioural determinations ${ }^{6}$. Therefore, the baby grows and develops with interference from the preset context of the cultural, social and historical background ${ }^{5-7}$, including the learning and living experiences/standards related to sex ${ }^{6}$. There is no doubt that acquisitions and changes in performance are related not only to the biological differences between sexes, but also to the socio-economic, cultural and family factors that tend to increase their influence with increasing age. This hypothesis could explain the increased motor disparities between sexes over the years ${ }^{7}$.

Research to identify performance differences in boys and girls began a long time $a^{9} 0^{8}$ with studies of children above four years of age $e^{9,10}$. On the other hand, there were few studies of motor development in children between 0 and 2 years ${ }^{1,4,11}$. Differences in the motor performance of boys and girls of school

1 Pós-Doutoranda em Ciências do Movimento Humano na Universidade Federal do Rio Grande do Sul (UFRGS); Rio Grande do SulBrasil. Docente da Universidade de Caxias do Sul (UCS) - Rua Francisco Getúlio Vargas 1130 - Bairro Petrópolis, $95070-560$ - Caxias do Sul, Rio Grande do Sul/Brasil.

2 PhD. em Health And Human Performance - Auburn University; Alabama - Estados Unidos da América. Docente da Universidade Federal do Rio Grande do Sul - Rua Felizardo, 750 - Jardim Botấnico - 90690-200 - Porto Alegre, Rio Grande do Sul/Brasil. Corresponding author: Raquel Sacani. E-mail: Raquel Saccani@yahoo.com.br

Suggested citation: Machado LDS, Ramos JLS, Machado MFAS, Antão JYFL, Santos SB, Bezerra IMP et al. Postural control in children born at term according to the Alberta Infant Motor Scale: Comparison between sexes. Journal of Human Growth and Development. 25(3): 364-370. Doi: http://dx.doi.org/10.7322/jhgd.106014

Manuscript submitted Oct 22 2014, accepted for publication Dec 192014. 
age are related to the opportunities offered to each individual ${ }^{12,13}$, which would also explain the fact that this discrepancy does not appear in children below two years of age, suggesting similar motor development until this later age ${ }^{1,14}$.

Results of the study of motor development difference during the first two years of life are insufficient and contradictory, especially considering that many studies either do not include this age group from birth ${ }^{11,15}$ or do not incorporate motor development aspects in the research ${ }^{1}$. Some studies suggest motor development similarities between sexes until two years of age; however, this is as a secondary result to other investigations ${ }^{1,14}$, or samples of small groups ${ }^{16}$.

The present research aimed to investigate differences between sexes in the motor development of children from birth until walking independently, having as its hypothesis a similarity in performance of the two sexes throughout the age range studied.

\section{METHOD}

This is a descriptive and observational research, cross-sectional in approach, adopted by the Committee of Ethics in Research at the Universidade Federal do Rio Grande do Sul (UFRGS) (14126). The sample was composed of 638 children from nursery schools, basic health units and health institutions, selected in an intentional and nonprobabilistic way, during the period 2009-2012, according to availability and in accordance with the following inclusion criteria: a) is aged between 0 and 18 months; b) has free informed consent signed by parents or caregivers; c) the instruments used in the research have been fully implemented. Excluded from the study were all children with: a) premature birth; b) musculoskeletal changes; c) neurological diseases; d) participation in intervention projects.

\section{Data collection instruments and procedures}

The motor development of children was evaluated through the Alberta Infant Motor Scale (AIMS), developed in Canada by Piper and Darrah in $1994^{17}$ and validated and standardized for the Brazilian population ${ }^{18-20}$. This instrument aims to evaluate the development of newborns at term and pre-term, from 38 weeks of gestational age up to 18 months of corrected age, through minimal accessories, for an average duration of 20 minutes. This is an objective assessment that checks for the acquisition of new motor skills during motor development until the point of independent locomotion is reached ${ }^{17,18}$.

The AIMS allows identification of the sequence of development within the control of basic postures including prone, supine, sitting and standing. It is composed of 58 items, divided into the four postural positions: 21 items in prone; 9 items in supine; 12 in the sitting posture and 16 in the standing position. Each of these items is evaluated in terms of different aspects of motor behaviour, such as the child's posture, his facility and the body surface where the weight is supported The motor performance of the child should be noted within each posture by assigning one point for each observed motor criterion and zero points for each criterion not observed. The total score ( 0 to 58 points) is the result of the sum of the criteria, which is transformed into a scale percentage of motor performance. This percentage is obtained through the relationship between age and total score, showing the level of child motor development ${ }^{18}$.

All tests were conducted in a peaceful atmosphere in the institutions of origin and filmed for later analysis of motor performance, having an average time of 20 minutes. During the assessment of the footing, three independent evaluators examined the free movement of the children, focusing on aspects such as the part of the body that sustains the weight, posture and antigravity movements. The index of agreement between the examiners was high (intra-class correlation coefficients between á $=0.86$ and á $=0.99$ ). The Friedman and Wilcoxon tests did not show significant differences between the responses of the three evaluators ( $p>0.05)$.

The children were assessed by the observation of 58 AIMS items in the four distributed postures, with the minimum of actions and facilitations. During the assessment, the examiner observed the movement of the child in each of the four positions and the way in which the child supports the body-i.e. how the child holds his weight-in addition to the quality of the posture and the antigravity movements. Auditory, verbal and visual stimuli were offered to encourage the child to acquire the desired positions, but no manipulations were performed on the child. After evaluating the items of motor development within those windows, the examiner took the points credited in the four postures to obtain the total AIMS score.

For sample characterization and pairing of the groups, a questionnaire on the characteristics of the child was delivered to the parents and/or legal guardians, addressing the following issues: birth date, sex, birth type, pregnancy weeks, the Apgar in the fifth minute, birth weight, birth length, cephalic perimeter and monthly family income.

\section{Data Analysis}

The analyses were performed in the program SPSS version 17.0. For comparisons between sexes, the Mann-Whitney $U$ test was used, along with parametric distribution of data (Shapiro-Wilk test). The significance level adopted was 5\% ( $\left.p d^{\prime \prime} 0.05\right)$.

\section{RESULTS}

As regards the general motor performance of the participants, it was observed that $69.7 \%$ of the children evaluated presented motor development appropriate for their age, and the values for each sex showed no differences between boys $(69.8 \%)$ and girls $(69.7 \%)$. Similarly, the suspicion of delay was observed in $20.6 \%$ of boys and $20.7 \%$ of the girls, and delays in the 
development were observed in equal proportions for each sex $(9.6 \%)$.

Table 1 illustrates that the motor performance of the children evaluated showed similarities between the two sexes. There is no significant difference between boys and girls in the total score and percentage for the four positions evaluated.

Table 1: Motor performance variables of participants and groups.

\begin{tabular}{|c|c|c|c|c|c|c|}
\hline GROUPS & ProneM $\pm S D$ & SupineM \pm SD & SittingM $\pm S D$ & StandingM \pm SD & Total scoreM \pm SD & PercentileM \pm SD \\
\hline General $(n=638)$ & $14,84 \pm 7,63$ & $7,46 \pm 2,45$ & $8,73 \pm 4,46$ & $8,71 \pm 5,98$ & $39,74 \pm 19,42$ & $45,09 \pm 27,03$ \\
\hline MG $(n=324)$ & $14,87 \pm 7,56$ & $7,54 \pm 2,33$ & $8,73 \pm 4,37$ & $8,81 \pm 5,98$ & $39,98 \pm 19,16$ & $45,69 \pm 27,20$ \\
\hline FG $(n=314)$ & $14,82 \pm 7,72$ & $7,38 \pm 2,56$ & $8,72 \pm 4,55$ & $8,61 \pm 5,99$ & $39,50 \pm 19,71$ & $44,47 \pm 26,88$ \\
\hline$p(\leq 0,05)$ & 0,87 & 0,59 & 0,65 & 0,65 & 0,76 & 0,52 \\
\hline
\end{tabular}

MG = Male Group; FG = Female Group

Table 2 presents the results according to age group. Performance differences were not observed between sexes from birth up to 18 months of age. After the age of 15 months, the results converge to equal values and total scores on the scale.

Table 2: Means and standard deviations of motot performance by postures, total score and percentile of each group by age

\begin{tabular}{|c|c|c|c|c|c|c|c|c|c|c|c|c|c|}
\hline $\begin{array}{c}\text { Age } \\
\text { Month } \\
\text { (n) }\end{array}$ & $\begin{array}{c}\text { Gender } \\
\text { (n) }\end{array}$ & $\begin{array}{l}\text { Prone } \\
\text { Md (SD) }\end{array}$ & $\mathbf{p}$ & $\begin{array}{l}\text { Supine } \\
\text { Md(SD) }\end{array}$ & p & $\begin{array}{l}\text { Sitting } \\
\text { Md(SD) }\end{array}$ & $\mathbf{p}$ & $\begin{array}{c}\text { Points AIMS } \\
\text { Standing } \\
\text { Md(SD) }\end{array}$ & $\mathbf{p}$ & $\begin{array}{l}\text { Total score } \\
\text { Md(SD) }\end{array}$ & $\mathbf{p}$ & $\begin{array}{l}\text { Percentile } \\
\text { Md(SD) }\end{array}$ & p \\
\hline RN (28) & $\begin{array}{l}M(13) \\
F(15)\end{array}$ & $\begin{array}{l}1,2(0,4) \\
1,1(0,3)\end{array}$ & 0,46 & $\begin{array}{c}2(0,8) \\
1,5(0,6)\end{array}$ & 0,07 & $\begin{array}{l}0,3(0,5) \\
0,3(0,5)\end{array}$ & 0,81 & $\begin{array}{c}1,1(0,3) \\
1(0)\end{array}$ & 0,28 & $\begin{array}{l}4,6(1,5) \\
3,8(1,2)\end{array}$ & 0,12 & $\begin{array}{l}50,9(29,2) \\
33,2(27,8)\end{array}$ & 0,12 \\
\hline $1^{\circ}(29)$ & $\begin{array}{c}M(13) \\
F(6)\end{array}$ & $\begin{array}{l}1,9(0,5) \\
1,9(0,8)\end{array}$ & 0,77 & $\begin{array}{l}2,2(0,7) \\
2,3(0,5)\end{array}$ & 0,75 & $\begin{array}{l}0,9(0,3) \\
0,8(0,4)\end{array}$ & 0,40 & $\begin{array}{l}1,1(0,3) \\
1,3(0,5)\end{array}$ & 0,13 & $\begin{array}{l}6,1(1,2) \\
6,2(1,5)\end{array}$ & 0,87 & $\begin{array}{l}28,4(19,8) \\
31,9(24,2)\end{array}$ & 0,87 \\
\hline $2^{\circ}(24)$ & $\begin{array}{l}M(12) \\
F(12)\end{array}$ & $\begin{array}{l}2,4(0,9) \\
2,4(0,8)\end{array}$ & 0,93 & $\begin{array}{l}3,4(0,7) \\
3,1(0,9)\end{array}$ & 0,23 & $\begin{array}{c}1,3(0,8) \\
1(0)\end{array}$ & 0,14 & $\begin{array}{l}1,8(0,6) \\
1,7(0,7)\end{array}$ & 0,72 & $\begin{array}{c}9(2,1) \\
8,2(1,6)\end{array}$ & 0,3 & $\begin{array}{l}39,7(27,1) \\
28,6(19,9)\end{array}$ & 0,3 \\
\hline $3^{\circ}(19)$ & $\begin{array}{l}M(8) \\
F(11)\end{array}$ & $\begin{array}{l}3,5(1,1) \\
3,5(0,9)\end{array}$ & 0,96 & $\begin{array}{l}4(0,5) \\
4(1,7)\end{array}$ & 0,54 & $\begin{array}{c}1,6(1,2) \\
1,7(1)\end{array}$ & 0,76 & $\begin{array}{c}2(0,8) \\
2,1(0,9)\end{array}$ & 0,93 & $\begin{array}{c}11,1(2,8) \\
11,3(3)\end{array}$ & 0,97 & $\begin{array}{l}34,9(29,1) \\
39,8(27,6)\end{array}$ & 0,97 \\
\hline $4^{\circ}(22)$ & $\begin{array}{l}M(12) \\
F(10)\end{array}$ & $\begin{array}{l}5,8(2,1) \\
4,0(1,3)\end{array}$ & 0,06 & $\begin{array}{l}5,5(1,7) \\
5,1(1,4)\end{array}$ & 0,61 & $\begin{array}{l}2,8(1,1) \\
2,3(1,2)\end{array}$ & 0,42 & $\begin{array}{c}2,6(1,1) \\
2(0,7\end{array}$ & 0,18 & $\begin{array}{l}16,7(4,9) \\
13,7(2,2)\end{array}$ & 0,08 & $\begin{array}{l}43,9(33,6) \\
18,3(14,1)\end{array}$ & 0,08 \\
\hline $5^{\circ}(31)$ & $\begin{array}{l}M(16) \\
F(15)\end{array}$ & $\begin{array}{l}6,2(1,9) \\
6,5(2,6)\end{array}$ & 0,95 & $\begin{array}{l}6,2(1,8) \\
6,1(1,9)\end{array}$ & 0,83 & $\begin{array}{l}3,3(1,6) \\
3,9(1,8)\end{array}$ & 0,32 & $\begin{array}{l}2,9(1,5) \\
2,2(0,8)\end{array}$ & 0,29 & $\begin{array}{l}18,6(5,4) \\
18,7(5,4)\end{array}$ & 0,95 & $\begin{array}{l}26,4(27,1) \\
27,2(27,9)\end{array}$ & 0,94 \\
\hline $6^{\circ}(24)$ & $\begin{array}{l}M(14) \\
F(10)\end{array}$ & $\begin{array}{c}7(3,0) \\
8,1(3,4)\end{array}$ & 0,38 & $\begin{array}{c}6,3(1,6) \\
6,8(2)\end{array}$ & 0,63 & $\begin{array}{l}4,4(2,7) \\
4,4(2,8)\end{array}$ & 0,9 & $\begin{array}{l}2,5(0,9) \\
2,5(0,9)\end{array}$ & 0,93 & $\begin{array}{l}20,2(6,1) \\
21,8(7,8)\end{array}$ & 0,64 & $\begin{array}{l}16,6(20,5) \\
25,1(28,7)\end{array}$ & 0,52 \\
\hline $7^{\circ}(35)$ & $\begin{array}{l}M(14) \\
F(14)\end{array}$ & $\begin{array}{l}11,3(2,5) \\
11,4(2,2)\end{array}$ & 0,43 & $\begin{array}{l}7,9(1) \\
8,1(1)\end{array}$ & 0,44 & $\begin{array}{l}8,5(1,7) \\
8,8(2,8)\end{array}$ & 0,28 & $\begin{array}{l}3,4(0,9) \\
4,1(1,2)\end{array}$ & 0,06 & $\begin{array}{l}31,1(3,7) \\
32,5(5,9)\end{array}$ & 0,22 & $\begin{array}{c}43,4(19,7) \\
52(24,3)\end{array}$ & 0,22 \\
\hline $8^{\circ}(25)$ & $\begin{array}{c}M(16) \\
F(9)\end{array}$ & $\begin{array}{c}15,9(4,5) \\
12,9(3,47)\end{array}$ & 0,11 & $\begin{array}{l}8,3(1) \\
8,2(1)\end{array}$ & 0,73 & $\begin{array}{l}9,5(2,3) \\
9,3(1,9)\end{array}$ & 0,75 & $\begin{array}{l}5,5(2,5) \\
4,1(2,4)\end{array}$ & 0,22 & $\begin{array}{l}39(8,8) \\
34,6(6)\end{array}$ & 0,17 & $\begin{array}{l}48,4(31,4) \\
30,9(21,5)\end{array}$ & 0,17 \\
\hline $9^{\circ}(37)$ & $\begin{array}{l}M(15) \\
F(22)\end{array}$ & $\begin{array}{l}14,4(5,3) \\
17,4(4,1)\end{array}$ & 0,09 & $\begin{array}{l}8,5(0,8) \\
8,5(0,9)\end{array}$ & 0,96 & $\begin{array}{l}9,7(3,1) \\
11,1(1,1)\end{array}$ & 0,44 & $\begin{array}{l}5,6(3,2) \\
6,5(2,4)\end{array}$ & 0,25 & $\begin{array}{c}38,2(10,6) \\
43,3(6,6)\end{array}$ & 0,18 & $\begin{array}{l}31,5(30,6) \\
42,4(26,6)\end{array}$ & 0,2 \\
\hline $10^{\circ}(44)$ & $\begin{array}{l}M(18) \\
F(26)\end{array}$ & $\begin{array}{l}17,1(5,7) \\
17,8(3,7)\end{array}$ & 0,51 & $\begin{array}{l}8,4(0,9) \\
8,4(1,3)\end{array}$ & 0,46 & $\begin{array}{l}10,9(1,1) \\
11,0(1,7)\end{array}$ & 0,38 & $\begin{array}{l}7,6(2,8) \\
6,0(2,9)\end{array}$ & 0,1 & $\begin{array}{l}43,5(9,1) \\
43,3(7,8)\end{array}$ & 0,8 & $\begin{array}{l}34,3(29,6) \\
28,9(27,7)\end{array}$ & 0,83 \\
\hline $11^{\circ}(44)$ & $\begin{array}{l}M(20) \\
F(24)\end{array}$ & $\begin{array}{l}20,4(0,9) \\
19,6(2,8)\end{array}$ & 0,75 & $\begin{array}{l}8,8(0,5) \\
8,8(0,4)\end{array}$ & 0,69 & $\begin{array}{l}11,6(0,9) \\
11,6(0,9)\end{array}$ & 0,42 & $\begin{array}{c}8,7(3,1) \\
9,7(3)\end{array}$ & 0,3 & $\begin{array}{l}49,5(3,6) \\
49,6(5,9)\end{array}$ & 0,4 & $\begin{array}{l}41(18,1) \\
45(22,9)\end{array}$ & 0,4 \\
\hline $12^{\circ}(35)$ & $\begin{array}{l}M(11) \\
F(15)\end{array}$ & $\begin{array}{c}20,8(0,6) \\
21(0)\end{array}$ & 0,26 & $\begin{array}{c}8,9(0,3) \\
9(0)\end{array}$ & 0,26 & $\begin{array}{l}11,6(0,7) \\
11,9(0,5)\end{array}$ & 0,24 & $\begin{array}{l}12,6(3,1) \\
13,3(2,9)\end{array}$ & 0,24 & $\begin{array}{l}53,8(3,6) \\
54,8(2,2)\end{array}$ & 0,08 & $\begin{array}{l}44,3(27,5) \\
51,1(17,8)\end{array}$ & 0,63 \\
\hline $13^{\circ}(54)$ & $\begin{array}{l}M(29) \\
F(25)\end{array}$ & $\begin{array}{l}20,7(1,1) \\
20,9(0,5)\end{array}$ & 0,86 & $\begin{array}{l}8,9(0,4) \\
8,8(0,4)\end{array}$ & 0,13 & $\begin{array}{l}11,9(0,4) \\
11,7(0,7)\end{array}$ & 0,17 & $\begin{array}{c}12,2(3,6) \\
13(3)\end{array}$ & 0,52 & $\begin{array}{l}53,7(4,2) \\
54,4(3,6)\end{array}$ & 0,75 & $\begin{array}{l}40,0(25,4) \\
42,9(23,5)\end{array}$ & 0,77 \\
\hline $14^{\circ}(42)$ & $\begin{array}{l}M(17) \\
F(19)\end{array}$ & $\begin{array}{c}20,5(2,2) \\
21(0,2)\end{array}$ & 0,13 & $\begin{array}{c}9(0) \\
9(0,2)\end{array}$ & 0,13 & $\begin{array}{c}11,1(1) \\
12(0)\end{array}$ & 0,91 & $\begin{array}{l}14,9(1,9) \\
15,5(1,4)\end{array}$ & 0,34 & $\begin{array}{l}56,8(1,9) \\
57,4(1,6)\end{array}$ & 0,13 & $\begin{array}{l}53,5(25,4) \\
61,7(21,9)\end{array}$ & 0,11 \\
\hline $15^{\circ}(41)$ & $\begin{array}{l}M(22) \\
F(19)\end{array}$ & $\begin{array}{l}21(0) \\
21(0)\end{array}$ & 1 & $\begin{array}{l}9(0) \\
9(0)\end{array}$ & 1 & $\begin{array}{c}12(0,2) \\
12(0)\end{array}$ & 0,35 & $\begin{array}{l}15,3(1,4) \\
14,5(2,5)\end{array}$ & 0,7 & $\begin{array}{l}57,3(1,5) \\
56,5(2,5)\end{array}$ & 0,72 & $\begin{array}{c}59,2(20,6) \\
52(30,7)\end{array}$ & 0,73 \\
\hline
\end{tabular}

Legenda: $M=$ male; $F=$ female; $M d=$ media; $S D=$ standard deviation; $n=$ number.

Figure 1 shows the similarity of performance curves of boys and girls from 0 to 18 months old, with behavioural variation in children of eight and nine months. In addition, the chart shows a greater number of postural acquisitions between four and twelve months, demonstrating non-linear

Figure 1: Curves of motor development according to sex and age development. A plateau in the performance of boys and girls appears from 15 months of age.

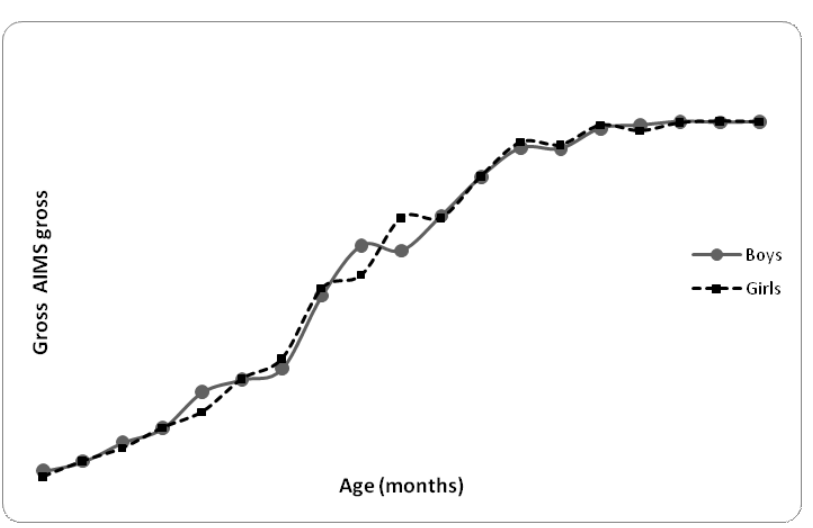


Figure 2 presents the performance curves in different postures, demonstrating again similarity between sexes, non-linear development in different postures and plateaus in the postural acquisitions.

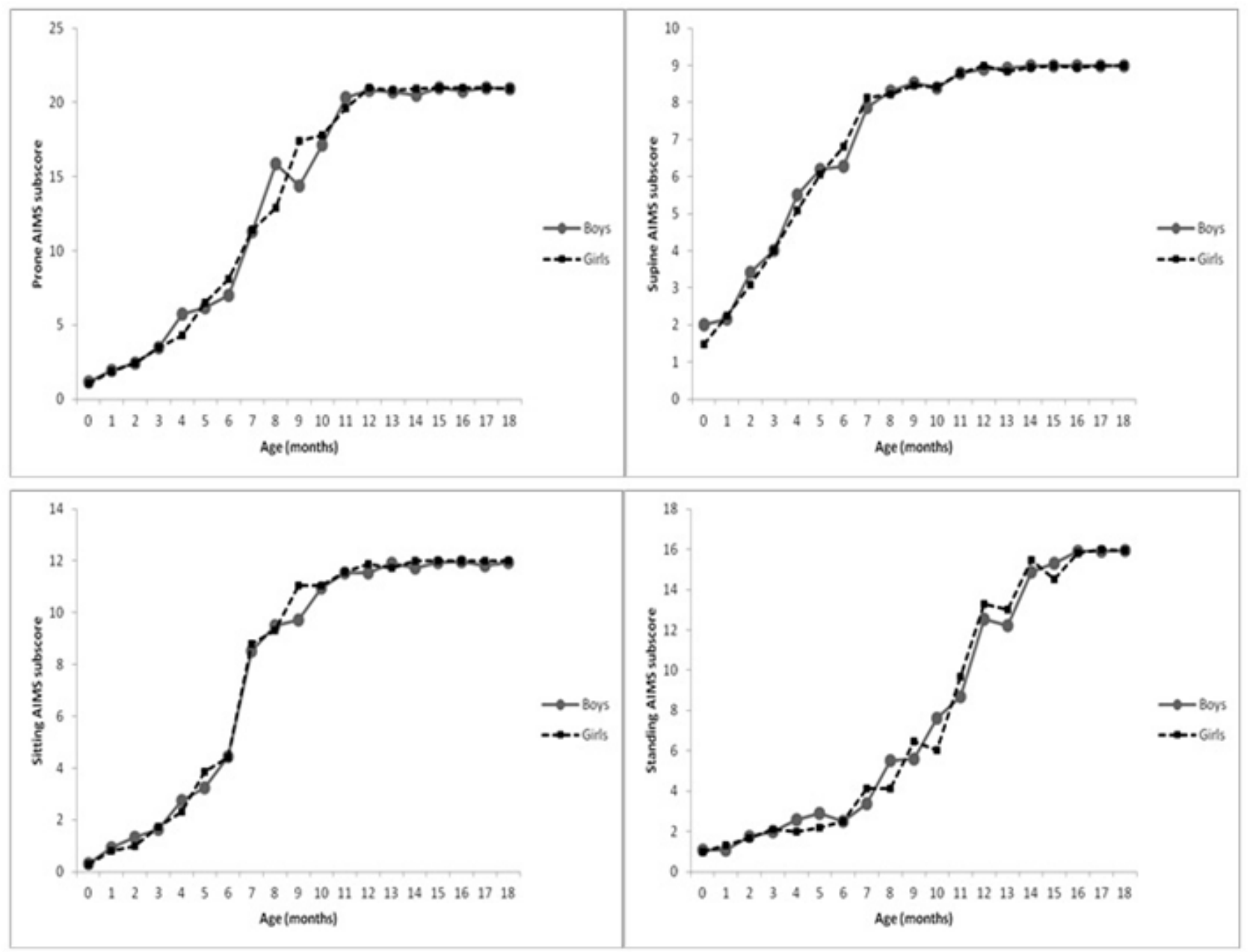

rigure L. Curves ot development ot prone, supıne, sıttıng and standıng postural acquisıtıon

\section{DISCUSSION}

The results of this survey support the initial hypothesis of this study of similarities in motor development performance between the sexes, with no differences in acquisition of postures represented by the values of the scores and percentiles. Although there are few investigations in this age group, previous researches have pointed to similarity in motor development of boys and girls ${ }^{11,14,15,17,21}$.

To develop the Alberta Infant Motor Scale, Piper and Darrah ${ }^{17}$ evaluated 2200 babies to compare their performance: they identified similarities between the groups which did not require the creation of development curves for each sex, as there was no difference in the patterns of movement to the age of 18 months $^{17}$. The study sought to establish reference values for the use of AIMS in the Netherlands and showed that there was no difference in the motor performance between the sexes within a population sample of 100 children under 12 months of age ${ }^{21}$.

Since 2006 the World Health Organization has shown concern with this investigative line, and demonstrates through a longitudinal multicentre study similarity in the gain of motor marks by boys and girls in different countries (Ghana, India,
Norway and the USA) up to 24 months of age ${ }^{15}$. In Brazil, Saccani and Valentini ${ }^{14}$ showed similarities in the motor performance of 571 babies ( 291 boys and 270 girls), although this was not the purpose of the study, by determining whether the results remained the same when considering the different age range of 0 to 18 months of age ${ }^{14}$. In Taiwan, Lung et al. ${ }^{11}$, in a longitudinal research with 1620 children, reported the existence of interaction between the sex of the child and its development after 36 months of age ${ }^{11}$. Below this age, only language and social aspects demonstrated a significant association.

However, with the advance of age, studies show the reversal of findings ${ }^{11}$, with the observation of disparities and heterogeneities in the acquisition and development of skills, which tend to accentuate puberty ${ }^{12,13}$. In this progression and emergence of differences in skills over the years, socio-cultural differences and parental practices appear to exert an influence on the development process, being crucial to the motor acquisitions of each sex: children will grow up through learning and being exposed to activities and experiences appropriate to each sex, as opposed to the different biological characteristics of boys and girls ${ }^{5}$. Therefore the observed differences in the performance of boys 
and girls are developed outside the environmental context and proposed practices for each sex, in accordance with the expectations of parents, educators and the age group to which children belong ${ }^{13}$.

In contrast, in terms of biological aspects, Pavlova et al.22 found differences between the sexes in the cortical region responsible for decisionmaking, ${ }^{22}$ although the emphasis has been on determining the influence of environmental factors on the attitude of children according to their sex $^{9}$, considering that tasks and experiences offered to boys and girls predispose them to differentiated growth and development ${ }^{23}$.

Therefore, the results of this study seem to show that up to about two years of age, exposure to different activities is not enough to generate distinct motor performance between boys and girls, which tends rather to be driven by the acquisition of independent walking. So, although children have the capacity to develop sensory motor skills, the attainment of certain skills will depend on the quantity of stimuli and experiences outside the context of attachment ${ }^{24-26}$.

To analyse the performance of the participants, it was found that the majority (69.7\%) presented appropriate motor development; congruent with results of national studies using the same instrument $\mathrm{t}^{27,28}$. However, other Brazilian studies with children in the same age group demonstrated motor performance lower than expected for age ${ }^{14,29,30}$. However, it is noteworthy that this sample was composed of premature infants, who formed part of the studies of Saccani et $a l .{ }^{14}$, Lee et al. ${ }^{30}$, Formiga et al. ${ }^{29}$.

The analysis of development of postural acquisitions in prone, supine, sitting and standing positions, independent of sex, has shown that those postural acquisitions follow a non-linear pattern, with the largest number of acquisitions occurring

\section{REFERENCES}

1. Eikmann SH, Lira PIC, Lima MC, Coutinho SB, Teixeira MLP, Ashworth A. Breast feeding and mental and motor development at 12 months in a low-income population in northeast Brazil. Paediatr Perinat Epidemiol.2007;21(2):129-37. DOI: http://dx.doi.org/10.1111/j.13653016.2007.00795.x

2. Pierce D, Munier V, Myers CT. Informing Early Intervention Through an Occupational Science Description of Infant-Toddler Interactions With Home Space. Am J Occup Ther. 2009; 63(3):273-87. DOI: http://dx.doi.org/10.5014/ ajot.63.3.273

3. Pretti LC, Milan JC, Foschiani MA. Caracterização dos fatores ambientais e o controle cervical de lactentes nascidos pré-termo. Fisioter Mov. 2010;23(2):239-50. DOI: http://dx.doi.org/ 10.1590/S0103-51502010000200008

4. To T, Guttmann A, Dick PT, Rosenfield JD, Parkin $\mathrm{PC}, \mathrm{Cao} \mathrm{H}$, et al. What factors are associated with poor developmental attainment in young Canadian children? J Public Health. 2004; 95(4): 258-63. between six and nine months. In Brazil, a pilot study demonstrated similar behaviour in development curves $^{16}$, as well as other national surveys with children from Goiás ${ }^{29}$ and São Paulo, both in Brazil ${ }^{30}$. Those findings refer to the idea of change in sensitivity of the items in the scale, which has already been pointed out in previous research ${ }^{14,31}$. Therefore, the range would be suitable to evaluate children within their first year; however, past twelve months, the main postural acquisitions (prone, supine and sitting) are attained in the absence of an instrument detailing enough items for children with delay-insensitive and normal motor performance.

For the total score, a plateau in the curve of development of children over 15 months was found, which suggests insufficient sensitivity to distinguish atypical behaviour in the extreme age range. This may be explained by the reduced number of items to differentiate the motor performance of those children, because much of the sample of this age range or above easily performed all items of evaluation. Similar results can be observed in Canadian reference values ${ }^{18}$.

Considering the similarity of results in motor performance between boys and girls up to 18 months old, the importance of research aimed at early identification of possible differences between the sexes is reinforced, as well as its relation to socio-cultural factors and parenting practices. Studies like this are necessary to determine the possible association of motor development with the care and stimulus aimed at children from birth, since children are exposed to experiences in line with expectations for each sex. It is also suggested that longitudinal studies be conducted to evaluate the powerful interactions between sex, culture and motor performance of children, determining when this environmental influence becomes determinant and decisive in the child's behaviour.

5. Haywood KM, Getchell N. Desenvolvimento motor ao longo da vida. Porto Alegre: Artmed; 2010.

6. Papalia DE, Olds SW, Feldman RT. Desenvolvimento Humano. Porto Alegre: Artmed; 2010.

7. Gallahue DL, Ozmunm JC. Compreendendo o Desenvolvimento motor: bebês, crianças, adolescentes e adultos. São Paulo: Phote; 2005.

8. Thomas JR, French KE. Gender differences across age in motor performance: A metaanalysis. Psychol Bull. 1985;98(2):206-82.

9. Cardoso FL. O conceito de orientação sexual na encruzilhada entre sexo, gênero e motricidade. Interam J Psychol. 2008; 42(1):69-79.

10. Schwengber MSV. Meninas e meninos apresentam desempenho motor distinto? Por quê? Rev Digital. 2009;14(131).

11. Lung FW, Chiang TL, Lin SJ, Feng JY, Chen PF, Shu BC. Gender differences of children's developmental trajectory from 6 to 60 months in the Taiwan birth cohort pilot study. Res Dev Disabil. 2011;32(1):100-106. DOI. http:// dx.doi.org/10.1016/j.ridd.2010.09.004

12. Valentini NC. Percepções de competência e 
desenvolvimento motor de meninos e meninas: Um estudo transversal. Movimento. 2002;8(2):51-62.

13. Carvalhal M, Vasconcelos-Raposo J. Diferenças entre gêneros nas habilidades: correr, saltar, lançar e pontapear. Motri. 2007;3(3):4456. DOI: http://dx.doi.org/10.6063/ motricidade.3(3).662

14. Saccani R, Valentini NC. Análise do desenvolvimento motor de crianças de 0 a 18 meses de idade: representatividade dos itens da Alberta Infant Motor Scale por faixa etária e postura. Rev Bras Crescimento Desenvolv Hum. 2010; 20(3): 753-64.

15. WHO Multicentre Growth Reference Study Group. Assessment of sex differences and heterogeneity in motor milestone attainment among populations in the WHO Multicentre Growth Reference Study. Acta Pædiatr. 2006;450:66-75. DOI: http://dx.doi.org/ 10.1111/j.1651-2227.2006.tb02377.x

16. Venturella C, Zanandrea G, Saccani R, Valentini NC. Desenvolvimento motor de crianças entre 0 e 18 meses de idade: Diferenças entre os sexos. Motricidade (Santa Maria da Feira). 2013;9(2):3-12. DOI: http://dx.doi.org/ 10.6063/motricidade.9(2).617

17. Piper MC, Darrah J. Motor assessment of the developing infant. Philadelphia WB: Saunders Company; 1994.

18. Piper MC, Pinnell LE, Darrah J, Maguire T, Byrne PJ. Construction and validation of the Alberta Infant Motor Scale (AIMS). Can J Public Health, $1992 ; 83(2): 46-50$.

19. Valentini NC, Saccani R. Brazilian Validation of the Alberta Infant Motor Scale. Phys Ther. 2012; 92(3):440-7. DOI: http://dx.doi.org/10.2522/ ptj.20110036

20. Saccani R, Valentini NC. Reference curves for the Brazilian Alberta Infant Motor Scale: percentiles for clinical description and followup over time. J Pediatr (Rio J). 2012;88(1):4047. DOI: http://dx.doi.org/10.2223/JPED.2142

21. Fleuren KMW, Smit LD, Stijnen T, Hartman A. New reference values for the Alberta Infant Motor Scale need to be established. Acta Paediatr. 2007;96(3):424-7. DOI. http:// dx.doi.org/10.1111/j.1651-2227.2007. 00111.x

22. Pavlova M., Guerreschi M, Lutzenberger W, Sokolov AN, Krageloh-Mann I. Cortical response to social interaction is affected by gender. Neuroimage. 2010;50(3):1327-1332. DOI: http://dx.doi.org/10.1016/j.neuroimage. 2009.12.096

23. Wanderlind F, Martins GDF, Hansen J, Macarini SM, Vieira ML. Diferenças de gênero no brincar de crianças pré-escolares e escolares na brinquedoteca. Paidéia. 2006;16(34):263-73. DOI: http://dx.doi.org/10.1590/S0103863X2006000200014

24. Clark JE, Metcalfe JS. (2002). The mountain of motor development: a metaphor. In: Clark JE, Humphrey JH. Motor development: research and reviews. V.2. Reston: NASPE; 2002; p.163-90.

25. Gabbard C, Caçola P, Rodrigues L. A New Inventory for Assessing Affordances in the Home Environment for Motor Development (AHEMD-SR). Early Child Educ J. 2008;36:5-9. DOI. http://dx.doi.org/10.1007/s10643-0080235-6

26. Nobre FSS, Costa CLA, Oliveira DL, Cabral DA, Nobre GC, Caçola P. Análise das oportunidades para o desenvolvimento motor (affordances) em ambientes domésticos no Ceará - Brasil. Rev Bras Crescimento Desenvolv Hum. 2009;19(1):9-18.

27. Manacero S, Nunes ML. Avaliação do desempenho motor de prematuros nos primeiros meses de vida na Escala Motora Infantil de Alberta (AIMS). J Pediatr (Rio J). 2008; 84(1): 53-59. DOI. http://dx.doi.org/10.1590/S002175572008000100010

28. Zanini PQ, Hayashida M, Hara PS, Lima AC, Castro SS, Bueno CF. Análise da aquisição do sentar, engatinhar e andar em um grupo de crianças pré-termo. Rev Fisioter Univ São Paulo. 2002; 9(2):57-62. DOI: http://dx.doi.org/ 10.1590/fpusp.v9i2.79653

29. Formiga CK, Linhares MB. Motor development curve from 0 to 12 months in infants born preterm. Acta Paediatr. 2011;100(3):379-84. DOI. http://dx.doi.org/10.1111/j.16512227.2010.02002.x

30. Lopes VB, Lima CD, Tudella E. Motor acquisition rate in brazilian infants. Infant Child Dev. 2009;18(2):122-32. DOI. http://dx.doi.org/ 10.1002/icd.595

31. Liao PJ, Campbell SK. Examination of the Item Structure of the Alberta Infant Motor Scale. Pediatr Phys Ther. 2004;16:31-8. DOI. http:// dx.doi.org/10.1097/010, 


\section{Resumo}

Introdução: as aquisições e mudanças no desenvolvimento motor e cognitivo de meninos e meninas não estão relacionadas apenas as diferenças biológicas existentes entre os sexos, mas também a fatores sócio econômicos, culturais e familiares. Objetivo: investigar as diferenças entre os sexos nas aquisições posturais antigravitacionais. Métodos: participaram deste estudo, 638 crianças nascidas atermo, de 0 a 18 meses (324 meninos e 314 meninas), residentes no Sul do Brasil, provenientes de Escolas de Educação Infantil. A Alberta Infant Motor Scale (AIMS) foi utilizada para avaliar o desempenho motor. Resultados: a maioria das crianças avaliadas demonstrou desempenho motor normal para idade $(69,7 \%)$, com desenvolvimento não linear e aparecimento de platôs nas aquisições posturais a partir dos 15 meses. Não foram detectadas diferenças significativas $(p>0,05)$ entre o desempenho motor de meninos e meninas dos 0 aos 18 meses de idade. Conclusão: o desenvolvimento motor foi semelhante entre os sexos nos primeiros anos de vida. Entretanto destaca-se que com o passar dos anos as diferenças sócio culturais e de práticas parentais exercem influências sobre o processo de aquisição e desenvolvimento de habilidades motoras, uma vez que, as crianças tem sido sendo expostas a experiências de acordo com as expectativas para cada gênero.

Palavras-chave: Desenvolvimento infantil, fatores de risco, sexos, atraso, avaliação. 